\title{
GRAMMATICAL WORDS DENOTING VAGUENESS IN JOSEPH CONRAD'S HEART OF DARKNESS AND THEIR TRANSLATIONS INTO SPANISH: A CORPUS APPROACH
}

\author{
Pablo Ruano San Segundo y Paloma Pizarro Seijas \\ Universidad de Extremadura
}

\begin{abstract}
In this article we use corpus tools to analyse two translations into Spanish of Heart of Darkness, the first made by García Ríos and Sánchez Araujo ([1976] 2005) and the second made by Diéguez Rodríguez (2002). Specifically, we examine the extent to which the two Spanish versions faithfully maintain the salient use of the grammatical words some, somebody, somehow, someone, something, sometimes and somewhere, which in the English text are profusely used to convey the well-known blurry atmosphere that dominates the story (Stubbs, 2005). In the first place, the frequency of these words in Heart of Darkness will be compared with their presence in a reference corpus formed by the rest of Conrad's novels. Then, thanks to the use of an aligned parallel corpus containing the English text and the two Spanish versions, the Spanish translators' rendering of the every grammatical word will be systematically scrutinized. The aim of the analysis is to show whether micro-textual shifts take place in the Spanish versions and, if so, their effects from a stylistic point of view.

Keywords: Heart of Darkness, vagueness, grammatical words, corpus approach, translation.
\end{abstract}

\section{ANÁLISIS DE LA ATMÓSFERA NEBULOSA A TRAVÉS DE LAS PALABRAS GRAMATICALES \\ EN DOS TRADUCCIONES ESPAÑOLAS DE HEART OF DARKNESS, DE JOSEPH CONRAD: UN ESTUDIO DE CORPUS}

\section{Resumen}

En este artículo se analizan, utilizando herramientas de corpus, las traducciones al español de Heart of Darkness llevadas a cabo por García Ríos and Sánchez Araujo ([1976] 2005) y Diéguez Rodríguez (2002). De forma más concreta, el estudio se centra en medir el grado de fidelidad de ambas versiones a la hora de mantener el uso de some, somebody, somehow, someone, something, sometimes and somewhere, que en el texto inglés desempeñan, 
debido a su alta frecuencia, un papel decisivo en la creación de la atmósfera nebulosa que domina la historia (Stubbs, 2005). En primer lugar, la frecuencia de estas palabras en Heart of Darkness será comparada con su presencia en un corpus de referencia formado por el resto de novelas de Conrad. A continuación, utilizando un corpus paralelo formado por el texto inglés y las dos traducciones objeto de análisis, se analizará de forma sistemática la traducción al español de cada uno de los ejemplos localizados. De esta manera, será posible calibrar las implicaciones que las distintas opciones escogidas por los traductores acarrean desde un punto de vista estilístico.

Palabras clave: Heart of Darkness, lenguaje vago, palabras gramaticales, enfoque de corpus, traducción.

\section{INTRODUCTION}

The use of corpus approaches in traditional descriptive translation studies is not new (see Laviosa, 2013). In fact, it can be traced back some twentyfive years ago, when Baker promoted the use of corpus methodologies «to uncover the nature of translated texts as a mediated communicative event» (Baker, 1993: 243). However, these approaches are becoming more sophisticated, as scholars learn more about, and refine, methods and areas of application $^{1}$. One of the areas of application in which corpus approaches are being used with increased frequency is literary translation analyses. Indeed, the conflation of corpus translation studies and disciplines such as corpus stylistics has made it possible to analyze literary translations using corpus methods. For example, the translated works of F. Scott Fitzgerald (Winters, 2005), Miguel de Cervantes (Ji, 2012), James Joyce (Patton \& Can, 2012), John Irving (Čermáková, 2015) and Charles Dickens (Ruano San Segundo, 2017) into German, Chinese, Turkish, Czech and Finnish (Čermáková, 2015) and Spanish respectively have been explored from this perspective. This article is intended to contribute another example to this branch of translation studies, which could be labelled corpus literary translation studies. We analyze two Spanish translations of Joseph Conrad's Heart of Darkness, one by García Ríos \& Sánchez Araujo ([1976] 2005) and the other by Diéguez Rodríguez $(2002)^{2}$. Specifically, we examine whether and to what extent the two versions maintain the salient use of the grammatical words some, somebody, somehow, someone, something, sometimes and somewhere, which in the English novel are used to convey vagueness. For example:

1 The use of corpus methods in translation studies include, among many others, the works of Baker (2004), Kruger, Wallmach \& Munday (2011), Zanettin (2012) and Sánchez Nieto (2015). For a comprehensive overview of corpus translation studies, see Laviosa (2013).

2 The main reason for choosing these two versions is that they were readily accessible to us and we could digitize them in order to create the aligned parallel corpus that we used to carry out the analysis (see Section 3). Other than that, any other Spanish translation of the novel would have been as suitable for analysis as the two scrutinized here. 
(1) His aspect reminded me of something I had seen — something funny I had seen somewhere (Conrad, 1973: 75).

The occurrences of the different realizations of $\operatorname{somE}^{3}$ are part of a wider net which contributes to the well-known lack of clarity that dominates the story (see Section 2). Using a corpus approach, Conrad's use of these grammatical words will be accurately measured and compared against the backdrop of a reference corpus containing the rest of his novels, thus ascertaining their stylistic saliency in Heart of Darkness. Using an aligned parallel corpus containing the English text and the two Spanish versions, the Spanish translators' rendering of some will then be systematically scrutinized in order to ascertain the extent to which the vagueness conveyed by the extensive use of the above-mentioned seven grammatical words is preserved. The aim of the analysis is to show whether microtextual shifts take place in the Spanish versions and, if so, their effects from a stylistic point of view.

The article begins with an overview of the expression of vagueness in Heart of Darkness (Section 2). This is followed by an explanation of the methodological procedure used to retrieve the hits for some from the novel and to identify their Spanish translations in the version by García Ríos \& Sánchez Araujo and the version by Diéguez Rodríguez (Section 3). Finally, the results are presented in Section 4 and analyzed in Section 5, where we show how the linguistic modifications made by the Spanish translators have stylistic consequences which affect the projection of the atmosphere of vagueness in the English text. The article concludes with some suggestions for future research in terms of analyzing translations of vague language in Heart of Darkness using corpus methodologies.

\section{Vagueness in Heart of DaRKNess}

Lack of clarity is one of the main themes of Heart of Darkness. Major places, for example, are not mentioned in the story. Although readers know that Marlow goes to Brussels before arranging his trip to the Belgian Congo and along the River Congo, these places are never actually named. Only the word Africa is mentioned, but just once throughout the story (Stubbs, 2005: 8). The timescale is often blurry too. Not only is the story told with flash-backs and flash-forwards, but Marlow's references to time are also vague (Stubbs, 2005: 8). Thus, the repairs of his steamer, for example, took him «some months»(Conrad, 1973: 30). Finally, characters' names are rarely mentioned, and they are identified instead by their roles in the story: the

3 For the sake of convenience, the lemma some - in upper case- will be used to refer to some, somebody, somehow, someone, something, sometimes and somewhere, even though we are aware that these seven words are different parts of speech. 
lawyer, the doctor, the manager, etc. (Stubbs, 2005: 8). In addition to places, the timescale and characters' names, the story is studded with other examples that contribute to a sense of vagueness. For instance, Kurtz dies uttering the famous «The horror! The horror!», but we do not know what he is referring to (LaBrasca, 1988), and Marlow, as he gets closer to Kurtz, indicates a series of signs he finds difficult to decode: the flat piece of board with some illegible faded pencil-writing on it, the Russian notes pencilled in the margin of a book which he thought was cipher or the round carved balls on slim posts near the Inner Station that turned out to be human skulls ${ }^{4}$.

At a purely linguistic level, this misty atmosphere has traditionally been explained in terms of Conrad's extensive and varied use of words denoting vagueness (Watt, 1988). Hazy words are indeed quite common: blurred, dark, darkly, darkness, dusk, fog, gloom, gloomy, haze, mist, misty, murky, shadow, shadowy, shade, shape, smoke, vapour, etc. Conrad's adjectival style in this novel also contributes to this effect (Senn, 1980). However, as Stubbs (2005: 10) argues in his ground-breaking corpus-stylistic approach to the novel, vagueness is also the consequence of the extensive use of grammatical words. He identifies around 100 occurrences of like (as a preposition) and over twenty-five occurrences of kind of and sort of, which often collocate with other expressions of vagueness (for example, the outlines of some sort of building). He also identifies around fifty occurrences of seemed, which contribute to the sense of blurriness (for example, seemed somehow to throw a kind of light). However, the most interesting discovery, in our view, is Conrad's extensive use of the words some, somebody, somehow, something, sometimes and somewhere. They are legion throughout the text, with more than 200 occurrences in a novel of fewer than 40,000 words, and much more frequent - comparatively speaking - than in a 710,000-word corpus of fiction and a one-million-word corpus of written English from the BNC (British National Corpus). Preserving them in translating the novel into another language is therefore vital in order to achieve the same stylistic effects as in the original. In this article, we analyze how García Ríos \& Sánchez Araujo (2005) on the one hand, and Diéguez Rodríguez (2002) on the other, translate these words into Spanish. To do so, we used a computer-assisted methodology to (i) retrieve all the occurrences of some from both Heart of Darkness and the remainder of Conrad's novels, which made it possible to ascertain the saliency of these grammatical words denoting vagueness against the backdrop of his bibliography, and (ii) identify and systematically scrutinize how the Spanish translators rendered each occurrence of these words. This methodology is explained below.

4 These and other aspects are further described and exemplified in detail by Stubbs (2005: 8-10). 


\section{Methodology}

This section is divided into two parts. First, the retrieval of some from Heart of Darkness and the rest of Conrad's works is carried out. Then, the identification of the translation of some by García Ríos \& Sánchez Araujo (2005) and Diéguez Rodríguez (2002) is explained. With regard to the retrieval of some from Conrad's works, on the one hand, a computer-assisted methodology was used. Specifically, the software tool WordSmith Tools 7 (Scott, 2016) was employed to identify the occurrences of the different grammatical words from Conrad's texts ${ }^{5}$. All these words share the root some-. This feature makes their simultaneous retrieval possible with the concordance search some*, since the asterisk replaces any character or group of characters in the concordance option in WordSmith. Figure 1 shows twenty examples of the 203 hits retrieved after some* from Heart of Darkness:

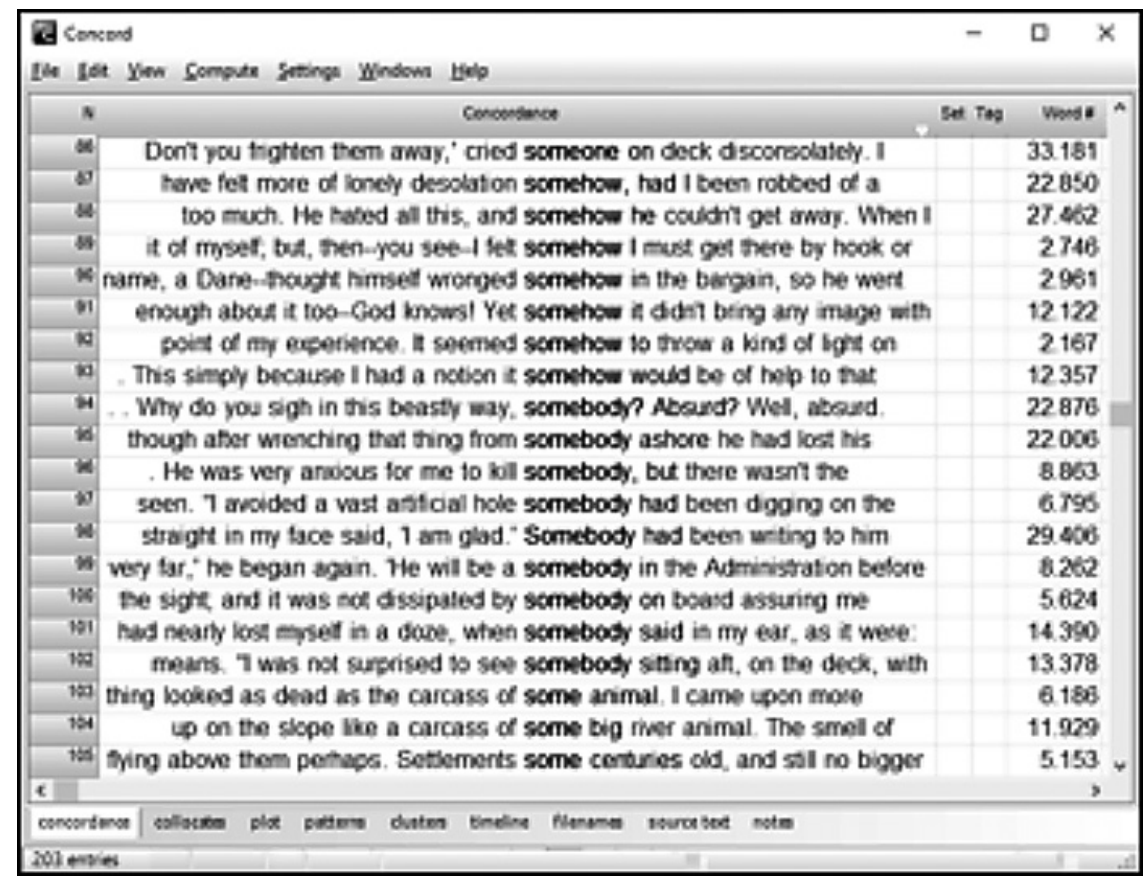

Figure 1. Screenshot showing 20 of the 203 hits retrieved after some* in Heart of Darkness.

5 Both Heart of Darkness and the remainder of Conrad's novels were downloaded from the Project Gutenberg website. Page numbers throughout the article, however, refer to the Penguin Modern Classics edition (Conrad, 1973). 
These 203 hits confirm Stubbs's (2005: 10) assertion that there are «over 200 occurrences of something, somebody, sometimes, somewhere, somehow and some», whose retrieval from the text is not explained by Stubbs. Specifically, the 203 occurrences of some correspond to seven different words: some, somebody, somehow, someone ${ }^{6}$, something, sometimes and somewhere. They are distributed as shown in Table 1.

Table 1. Occurrences of SOME in Heart of Darkness

\begin{tabular}{|l|c|}
\hline \multicolumn{1}{|c|}{ Word } & Frequency \\
\hline some & 101 \\
\hline somebody & 9 \\
\hline someone & 1 \\
\hline something & 52 \\
\hline somewhere & 9 \\
\hline sometimes & 24 \\
\hline somehow & 7 \\
\hline Total & $\mathbf{2 0 3}$ \\
\hline
\end{tabular}

Stubbs (2005: 10) compares his results with those retrieved from two corpora - a 710,000-word corpus of fiction and a one-million-word corpus of written English from the BNC-, showing that SOME is statistically more significant in Heart of Darkness. Here, however, we opted for comparing the significance of these 203 occurrences with the remainder of Conrad's novels ${ }^{7}$, in order to ascertain the saliency of some in Heart of Darkness as a Conradian stylistic feature within the novel. The results obtained from each novel are shown in Table $2^{8}$.

As can be observed, Conrad's use of some in Heart of Darkness (0.53) is higher than in any of his novels. Actually, it is significantly higher than his average use of some, which stands at $0.36 \%$. This fact reinforces Stubbs's findings and demonstrates the stylistic significance ${ }^{9}$ of some in Heart of Dark-

6 Someone is not mentioned by Stubbs, even though it occurs once in the novel: «"Don't! Don't you frighten them away", cried someone on deck disconsolately» (Conrad, 1973: 97).

7 Essays, stories and collections of short stories were not included in the reference corpus. His well-known collaborations with Ford Madox Ford were not included either, for obvious reasons.

8 In addition to some, somebody, somehow, someone, something, sometimes and somewhere, several occurrences of somewhat were also found. Needless to say, these occurrences were not ruled out.

9 Stylistic significance is understood here as a frequency deviance which results in literary foregrounding, following Leech \& Short's (2007: 39) notion of style. 
Table 2. Hits for SOME retrieved from Conrad's novels

\begin{tabular}{|l|c|c|c|c|}
\hline \multicolumn{1}{|c|}{ Novel } & Published & Words & Hits for some* & \% of some* \\
\hline Almayer's Folly & 1895 & 12,410 & 55 & 0.44 \\
\hline An Outcast of the Islands & 1896 & 107,354 & 313 & 0.29 \\
\hline The Nigger of the «Narcissus» & 1897 & 54,802 & 176 & 0.32 \\
\hline Heart of Darkness & 1899 & 38,767 & 203 & 0.53 \\
\hline Lord Jim & 1900 & 131,481 & 491 & 0.37 \\
\hline The End of the Tether & 1902 & 53,066 & 177 & 0.33 \\
\hline Typhoon & 1902 & 31,469 & 115 & 0.36 \\
\hline Nostromo & 1904 & 171,217 & 486 & 0.28 \\
\hline The Secret Agent & 1907 & 90,770 & 280 & 0.30 \\
\hline Under Western Eyes & 1911 & 112,799 & 496 & 0.43 \\
\hline Chance & 1913 & 138,638 & 606 & 0.43 \\
\hline Victory & 1915 & 118,528 & 477 & 0.40 \\
\hline The Shadow Line & 1917 & 39,940 & 166 & 0.41 \\
\hline The Arrow of Gold & 1919 & 108,248 & 473 & 0.43 \\
\hline The Rescue & 1920 & 134,758 & 424 & 0.31 \\
\hline
\end{tabular}

ness, thereby pointing at the importance of preserving it when translating the novel into other languages.

With regard to the identification of the Spanish translations of these 203 occurrences of some in Heart of Darkness, on the other hand, the translations by García Ríos \& Sánchez Araujo and by Diéguez Rodríguez were examined manually by creating an English-Spanish aligned corpus containing Heart of Darkness and the two translated texts. An excerpt from the corpus containing one occurrence of some is shown in Table $3^{10}$.

The alignment of the three texts makes it possible to gauge systematically how the translators approach this Conradian stylistic feature. However, it also enables a methodical analysis of how each one individually renders the various occurrences of some into Spanish, and a comparison of how the same examples are dealt with in each translation, which can contribute to research on translators' stylistic preferences. In the case of the example

\footnotetext{
${ }^{10}$ In order to be loaded in a word processor, the two Spanish translations of Heart of Darkness had to be converted into plain text files. To do so, the texts were scanned and processed with an OCR (Optical Character Recognition) software (the norm for digitized texts). Needless to say, typographical errors were found. However, they do not affect the search process, since the occurrences of some were manually located using the English text as a reference.
} 
Table 3. Excerpt from aligned corpus containing Heart of Darkness and the two Spanish translations

\begin{tabular}{|c|c|c|}
\hline Heart of Darkness & arcía Ríos Ė Sánchez Araujo & Diéguez Rodríguez \\
\hline $\begin{array}{l}{[\ldots] \text { He withdrew upon }} \\
\text { some threat of legal pro- } \\
\text { ceedings, and I saw him } \\
\text { no more; but another } \\
\text { fellow, calling himself } \\
\text { Kurtz's cousin, appeared } \\
\text { two days later, and was } \\
\text { anxious to hear all the } \\
\text { details about his dear rela- } \\
\text { tive's last moments. }\end{array}$ & $\begin{array}{l}\text { [...] Se retiró amenazando } \\
\text { con iniciar un proceso } \\
\text { judicial y no le volví a ver; } \\
\text { pero otro individuo, que } \\
\text { dijo ser primo de Kurtz, } \\
\text { se presentó dos días más } \\
\text { tarde, ansioso por oír to- } \\
\text { dos los detalles sobre los } \\
\text { últimos momentos de su } \\
\text { querido pariente. }\end{array}$ & $\begin{array}{l}\text { [...] Se retiró con la ame- } \\
\text { naza de emprender accio- } \\
\text { nes legales y no volví a } \\
\text { verlo. Sin embargo, otro } \\
\text { individuo, que decía ser el } \\
\text { primo de Kurtz, apareció } \\
\text { dos días después, impa- } \\
\text { ciente por escuchar todos } \\
\text { los detalles relativos a los } \\
\text { últimos momentos de su } \\
\text { querido pariente. }\end{array}$ \\
\hline
\end{tabular}

shown in the table, for instance, we can see an occurrence of some which illustrates Marlow's vague memory of the Company representative's threat when he visits Marlow to collect the packet of papers Kurtz has entrusted to him before he died. Marlow cannot recall the specific threat, but just that it was «some threat of legal proceedings». This is a clear example of the lack of clarity conveyed by the extensive use of SOME throughout the story. In the Spanish versions, however, neither of the two texts preserves the vagueness of the original, as can be seen in the table. García Ríos \& Sánchez Araujo, on the one hand, omit the grammatical word, turning an instance of Marlow's unreliable memory into a simple narration of the facts («se retiró amenazando con iniciar un proceso judicial» / he withdrew threatening to start a legal proceeding; our translation) where no vagueness is perceived. Diéguez Rodríguez, on the other hand, translates some into Spanish using a word denoting specificity («la» / the), also nullifying the blurry effect achieved by the grammatical word («se retiró con la amenaza de emprender acciones legales» / he withdrew with the threat of taking legal action; our translation). Far from being stylistically harmless, these microtextual shifts, as shown below, affect the projection of the vague atmosphere that characterizes the English text. The results for the rendering of each of the 203 occurrences in each version are shown in Section 4.

\section{Results}

Following a search for how the 203 occurrences of some were rendered in the two Spanish versions, the translators' strategies can be divided into three self-contained categories: a faithful translation of some, a translation 
of some using a word denoting specificity (such as the example by Diéguez Rodríguez in Table 3) and the omission of some (such as García Ríos \& Sánchez Araujo's example in Table 3). The frequency with which each of these strategies is used in each version is shown in Table 4 .

Table 4. Strategies used to translate grammatical words into Spanish

\begin{tabular}{|l|r|r|r|r|}
\hline \multicolumn{1}{|c|}{ Strategy } & $\begin{array}{r}\text { García Ríos Eे } \\
\text { Sánchez Araujo }\end{array}$ & $\%$ & $\begin{array}{c}\text { Diéguez } \\
\text { Rodríguez }\end{array}$ & $\%$ \\
\hline Faithful translation & 175 & 86.2 & 147 & 72.4 \\
\hline $\begin{array}{l}\text { Grammatical word translated us- } \\
\text { ing a word denoting specificity }\end{array}$ & 19 & 9.4 & 29 & 14.3 \\
\hline Grammatical word omitted & 9 & 4.4 & 27 & 13.3 \\
\hline Total & $\mathbf{2 0 3}$ & $\mathbf{1 0 0 . 0}$ & $\mathbf{2 0 3}$ & $\mathbf{1 0 0 . 0}$ \\
\hline
\end{tabular}

As may be expected, the most frequent strategy used in both translations involves preserving the grammatical word denoting vagueness. However, it is indeed interesting that both versions contain a significant number of examples in which these words are not translated properly, and are sometimes even omitted. In the case of García Ríos \& Sánchez Araujo, these examples amount to twenty-eight, that is, $13.8 \%$ of the total. In the case of Diéguez Rodríguez, there is a greater number of occurrences of some which are either omitted or translated using a word denoting specificity, with fifty-six examples $(27.6 \%)$. The twenty-eight examples in the version by García Ríos \& Sánchez Araujo and the fifty-six in the translation by Diéguez Rodríguez all affect the blurry atmosphere portrayed by Conrad in the original text. This loss is analyzed below, suggesting alternatives (where necessary) which in our view would have resulted in a more adequate translation from a stylistic point of view.

\section{Analysis}

The analysis is divided as follows. Firstly, we analyze four examples in which one of the two versions does not translate some accurately, while the other one does. The first two examples discussed involve two cases of omission (one per version) and the remaining two involve cases in which some is translated using a word denoting specificity (also one per version). Finally, two more examples are analyzed in which none of the two versions preserves the role conveyed by the use of some. The first case will be an example in which both translations omit the grammatical word, while the second case will be an example in which they translate the grammatical word using a word denoting specificity. In both cases, we provide an alternative transla- 
tion which, in our view, would have preserved the role conveyed by the use of some. The six examples discussed will not only illustrate the literary loss when SOME is not rendered faithfully ${ }^{11}$, they will also demonstrate that, if grammatical words are not translated accurately, it is not so much because they are difficult to translate but because translators do not seem to notice their stylistic significance in the source text.

The first example to be analyzed involves the occurrence of some in the prepositional phrase «in some way» shown in (2). This phrase is used to convey vagueness. It makes it clear that those who accuse the native of causing a fire which burnt down a shed could not demonstrate how he did it or whether he caused it at all, thereby amplifying the unreliable knowledge that dominates the story.

(2) A nigger was being beaten near by. They said he had caused the fire in some way; be that as it may, he was screeching most horribly (Conrad, 1973: 34).

This unreliable knowledge is faithfully maintained in the version by García Ríos \& Sánchez Araujo, as can be observed in (2a). Their use of de alguna manera preserves, through a literal translation, the vagueness intended by Conrad's prepositional phrase, as alguna is pragmatically equivalent to some $^{12}$. In the version by Diéguez Rodríguez, however, there is no trace of this unreliable knowledge from the original text. As can be seen in (2b), the prepositional phrase is omitted, nullifying the unknown cause and, consequently, the vagueness conveyed by Conrad through the use of some. It is clear, then, that the translation of (2) by García Ríos \& Sánchez Araujo is more accurate from a stylistic point of view.

(2a) Estaban azotando a un negro cerca de allá. Decían que él había provocado el incendio de alguna manera; sea como fuere, estaba dando horribles alaridos (García Ríos \& Sánchez Araujo, 2005: 51).

(2b) Cerca de allí estaban golpeando a un negro. Decían que él era el culpable del incendio; tanto si era cierto como si no, lo cierto es que sus gritos eran espantosos (Diéguez Rodríguez, 2002: 53).

The second example to be analyzed involves the occurrence of some shown in (3), which illustrates the undefined timescale of the story, as mentioned in

11 Throughout this section, faithfulness should be understood within the framework of pragmatic equivalence discussed by Rabadán (1991) or Baker (2011: 217), among others.

${ }_{12}$ This is the definition of alguna according to the Dictionary of the Spanish Royal Academy (Diccionario de la Real Academia): «alguno, na. 1. adj. indef. Expresa que no se conoce o no se desvela la existencia de aquello denotado por el nombre al que modifica» [indefinite adjective; used to express that the existence of the noun which it modifies is neither known nor specified (our translation)]. 
Section 2. This occurrence of some is used to quantify, in a blurry way, the time Marlow spent repairing his steamer; Marlow cannot recall how long it took him to repair the boat, but only that it «took some months».

(3) As a matter of fact, I had plenty to do in fishing my command out of the river. I had to set about it the very next day. That, and the repairs when I brought the pieces to the station, took some months (Conrad, 1973: 30).

In this case, it is the translation by García Ríos \& Sánchez Araujo which does not maintain the vagueness observed in the original. As can be seen in (3a), they provide a word-by-word translation of the sentence «That, and the repairs when I brought the pieces to the station, took some months» [«Esto y las reparaciones cuando hube traído los trozos a la estación, llevaron meses»], except for the grammatical word some («took some months» [«llevaron meses»]). It is true that llevaron meses does not make the number of months explicit or any clearer. Nevertheless, the omission of some eliminates the emphasis observed in the original, which helps to reinforce the imprecise timescale. This emphasis is not lost in the translation by Diéguez Rodríguez. As can be seen in (3b), he maintains the vagueness conveyed by some by using the Spanish pragmatically equivalent algunos. This option is not only linguistically more faithful to the original, but also more accurate from a stylistic point of view, as it highlights, like the original text, Marlow's difficulties in recalling the exact number of months that took him to repair the steamer.

(3a) En realidad, tenía bastante con sacar mi barco del río. Me tuve que poner a ello al día siguiente. Esto y las reparaciones cuando hube traído los trozos a la estación, llevaron meses (García Ríos \& Sánchez Araujo, 2005: 47).

(3b) En realidad, supuso bastante trabajo sacarlo del río, tarea que debí emprender al día siguiente. Eso y las reparaciones necesarias, una vez que conseguí que llevaran los repuestos a la delegación, me llevaron algunos meses (Diéguez Rodríguez, 2002: 47).

The frequency with which some is omitted is significantly different in each version. In the translation by García Ríos \& Sánchez Araujo, on the one hand, nine omissions were identified. In the one by Diéguez Rodríguez, on the other hand, up to twenty-seven omissions were found, as shown in Table 4 . This naturally results in a substantial difference in terms of how the blurriness is projected, so that the effect is less perceptible in the translation by Diéguez Rodríguez. The nine omissions in the text by García Ríos \& Sánchez Araujo, however, also affect the projection of the vagueness which characterizes the English text, as example (3a) has demonstrated. Finally, the fact that translators frequently omit some suggests that they seem not to have noticed the role of these grammatical words; otherwise they would most 
probably have preserved them in Spanish, especially since rendering them into Spanish poses no difficulties for translation, as shown in (2a) and (3b).

With regard to the cases in which the translators render some using a word denoting specificity, the examples identified seem less damaging than when the grammatical word is omitted. However, they are more numerous -nineteen instances in the case of García Ríos \& Sánchez Araujo and twenty-nine in the case of Diéguez Rodríguez - and they may also entail a significant loss of style. Take for example the occurrence of some in the prepositional phrase "with some sort of action» shown in (4), which corresponds to the moment in the story when Marlow and the pilgrims are attacked by the natives and the helmsman is wounded by a spear, dying soon afterwards. Marlow now expects Kurtz to be dead too, and this thought terrifies him. The use of «with some sort of action» helps to reinforce the vagueness when he pictures Kurtz. This, in turn, fits with the blurriness projected by Marlow when he tells the story and gives details of Kurtz, thereby making him appear to be shrouded in mystery, as he seems to Marlow before they finally meet.

(4) The man presented himself as a voice. Not of course that I did not connect him with some sort of action. Hadn't I been told in all the tones of jealousy and admiration that he had collected, bartered, swindled, or stolen more ivory than all the other agents together? That was not the point (Conrad, 1973: 67).

The translation of some in this prepositional phrase poses no difficulties. In fact, García Ríos \& Sánchez Araujo maintain the vagueness through the use of the Spanish pragmatically equivalent algún («con algún tipo de actividad»), as can be seen in (4a). This translation preserves the original aura of mystery surrounding Kurtz during Marlow's tale. In the case of Diéguez Rodríguez, however, a translation denoting specificity was found, as can be observed in (4b). Instead of «with some sort of activity» (con algún tipo de actividad), Diéguez Rodríguez suggests that Marlow did not connect Kurtz with any activity (ninguna actividad). That is, Marlow expresses certainty (even though this certainty consists of categorically denying the sort of activity he is referring to) when he expresses his thoughts about Kurtz. This choice nullifies Marlow's unreliability when he wonders about Kurtz. Thus, even though both versions are almost identical linguistically speaking, it seems clear that the translation by García Ríos \& Sánchez Araujo is more accurate from a stylistic point of view, as it preserves the literary value of some.

(4a) El hombre se me presentaba como una voz. Naturalmente, no es que no le asociara con algún tipo de actividad. ¿Acaso no me habían dicho en todos los tonos posibles de envidia y admiración que él había recogido, trocado, 
timado o robado más marfil que todos los demás agentes juntos? Eso no era lo importante (García Ríos \& Sánchez Araujo, 2005: 90).

(4b) Para mí, aquel hombre era una voz. No es que no lo relacionara con ninguna actividad. Al contrario, había escuchado, con todos los matices de la envidia y la admiración, cómo había reunido, conseguido mediante trueques, estafado a los nativos, o robado, más marfil que todos los demás agentes juntos. No, no era eso (Diéguez Rodríguez, 2002: 107).

A similar loss can be observed in the translation of some in (5). In this case, some is used in Marlow's reflection on the struggle between life and death just after Kurtz dies, when he falls ill and nearly dies himself. He comes to the conclusion that, while Kurtz had something to say, he did not. This makes Marlow realize that Kurtz was a remarkable man and that «life is a greater riddle than some of us think it to be». This use of some reinforces Marlow's unreliability by not specifying who these people are - or at least what kind of people - who do not consider life to be such a great riddle.

(5) If such is the form of ultimate wisdom, then life is a greater riddle than some of us think it to be (Conrad, 1973: 101).

In this case, it is the version by García Ríos \& Sánchez Araujo which fails to maintain the uncertainty found in the English text. They opt for a specific translation, as shown in (5a). Thus, it is la mayoria de nosotros [the majority of us] rather than «some of us» who thinks that life is not such a great riddle. This choice nullifies the original imprecise effect achieved by some, since Marlow is referring to only a few - unknown- people and not to the majority. As can be seen in (5b), this vagueness is clearly better preserved by Diéguez Rodríguez through the use of the Spanish pragmatically equivalent algunos. In his version, it is not the majority of people but only some of them who think that life is not such a great riddle (lo que algunos creemos), and this faithful rendering of some maintains the blurry tone of the English text.

(5a) Si tal es la forma de la sabiduría última, entonces la vida es un enigma mayor de lo que la mayoría de nosotros cree (García Ríos \& Sánchez Araujo, 2005: 128).

(5b) Si tal es la forma de sabiduría definitiva, entonces la vida es un enigma mayor de lo que algunos creemos (Diéguez Rodríguez, 2002: 157).

The translation by García Ríos \& Sánchez Araujo shown in (5a) and the one by Diéguez Rodríguez shown in (4b) demonstrate how rendering some by resorting to words denoting specificity can affect, albeit not so conspicuously as in cases where some is omitted, the blurriness conveyed by the use of grammatical words. It is true that the use of ninguna in (4b) and la mayoría in (5a) does not affect the reading of the texts at all and that, grammati- 
cally speaking, they are perfectly valid choices. However, these choices have an impact on the translated version from a stylistic point of view. This impact has been clearly illustrated by the other translation discussed for each example - the one by García Ríos \& Sánchez Araujo shown in (4a) and the one by Diéguez Rodríguez shown in (5b) - , which, in addition, have demonstrated how vagueness can be maintained in Spanish through the use of grammatical words. These examples also reinforce the idea that the translators did not recognize the role of some in the original novel, since the translation of the concept, as shown in (4a) and (5b), does not actually pose linguistic difficulties.

Finally, there are also worth analyzing examples in which the same occurrence of SOME is either omitted or translated using a word denoting specificity in the two Spanish versions. An example of each will now be discussed. Since neither translation seems, in our view, to be stylistically accurate, we will provide an alternative option, thereby demonstrating that rendering some into Spanish is not problematic. The two examples analyzed will also further demonstrate that the mistranslation of some is a consequence of the translators not having noticed its stylistic value in the source text.

The first of the two examples to be analyzed is the occurrence of somewhere shown in (6). As in example (3), the excerpt corresponds to the moment in the story when Marlow arrives at the Central Station and finds that the steamer that he is going to command has sunk. Specifically, the use of somewhere refers to those men who appear from amongst the buildings to take a look at Marlow when he arrives. When he is telling the story, Marlow does not know where they go when they disappear. He emphasizes this fact not only by saying that they «retired out of sight», but also by adding «somewhere» afterwards, as can be seen in the example.

(6) White men with long staves in their hands appeared languidly from amongst the buildings, strolling up to take a look at me, and then retired out of sight somewhere (Conrad, 1973: 30).

Conrad's use of somewhere is not necessary from a grammatical point of view to make sense of the sentence — «and then retired out of sight»— or to add supplementary information - the sentence does not lack any essential facts without the adverb. However, somewhere emphasizes the blurriness conveyed by Marlow in telling the story, as it helps to stress the little knowledge he has about the white men. The reader does not discover their names or any further information about them and does not know where they go after taking a look at Marlow, only learning that they retire somewhere. In both Spanish versions, however, the translators omit the adverb in their texts, as can be seen in $(6 \mathrm{a})$ and $(6 \mathrm{~b})$ : 
(6a) Hombres blancos con largos cayados aparecieron lánguidamente entre los edificios, acercándose a mirarme, y después desaparecieron de mi vista (García Ríos \& Sánchez Araujo, 2005: 47).

(6b) Entre las construcciones vi asomarse, de bastante mala gana, a algunos hombres blancos con cayados que se acercaban a comprobar quién era yo y luego desaparecían de mi vista (Diéguez Rodríguez, 2002: 46).

This omission of somewhere partially nullifies the vagueness conveyed by Conrad in the original text. Preserving this vagueness, however, would not actually have been complicated. In fact, and even though there is no equivalent adverb in Spanish to somewhere, a simple prepositional phrase containing the adjective algún («hacia algún lugar» [«towards some place»]) would have sufficed to achieve a more accurate translation of the excerpt, thereby maintaining the emphasis upon Marlow's well-known unreliable knowledge.

A similar loss was detected in the translation of the occurrence of some shown in (7). The excerpt corresponds to the moment of the story where Marlow is lying on the deck listening to the manager and his uncle talk about Kurtz and the so-called «wandering trader - a pestilential fellow» (Conrad, 1973: 46) who is supposed to be in Kurtz's district. The uncle does not like him and suggests his nephew get rid of him, as he does not want anyone challenging his authority. Marlow has no clue who this man might be, which is why he refers to him as some man, reinforcing the aura of mystery surrounding everything about Kurtz in Marlow's tale.

(7) Who was it they were talking about now? I gathered in snatches that this was some man supposed to be in Kurtz's district, and of whom the manager did not approve (Conrad, 1973: 46).

In the two Spanish versions, however, some is translated using a word denoting specificity. Both García Ríos \& Sánchez Araujo, on the one hand, and Diéguez Rodríguez, on the other, resort to the indefinite article un $[a / a n]$, as can be observed in (7a) and (7b) respectively. This strategy is actually fairly common in the examples found in both versions in which some is translated using a word denoting specificity ${ }^{13}$. In principle, this choice seems a valid option, since the meaning conveyed is practically the same as in the original text. However, the systematic way in which the indefinite article is used in the two Spanish versions nullifies the stylistic value of some in the English text. In the particular case of (7a) and (7b), for instance, by referring to the character as un hombre [a man], the emphasis on Marlow's unreliable knowledge indicated by some is lost. Even though the man is still unknown,

13 Specifically, sixteen examples were found in the translation by García Ríos \& Sánchez Araujo and twenty-four in the one by Diéguez Rodríguez. 
he is no longer some unknown man, but $a$ specific unknown man. Preserving this emphasis upon Marlow's unreliable knowledge in Spanish would not have been difficult. For example, the use of the Spanish pragmatically equivalent algún would have created the same effect as in the original («[...] que se trataba de algún hombre que debía [...]», for instance), thereby maintaining the Conradian stylistic trait.

(7a) Deduje de los fragmentos que se trataba de un hombre que debía estar en el distrito de Kurtz (García Ríos \& Sánchez Araujo, 2005: 61).

(7b) ¿De quién hablaban ahora? Por lo poco que oí, deduje que se trataba de un hombre que debía de andar cerca de la zona asignada a Kurtz y cuya conducta no aprobaba el director (Diéguez Rodríguez, 2002: 74).

In light of these examples, it is clear that if the translators did not maintain the grammatical words in their versions it is not because a pragmatic equivalence in Spanish, but because they had not noticed the stylistic value of the way in which Conrad used them.

To conclude, the occurrences of some analyzed throughout the article have demonstrated how literary translation studies can benefit greatly from the use of corpus approaches. As has been shown, an inconspicuous but stylistically significant element can be identified and analyzed in different translated versions of a literary text using corpus methodologies, gauging whether and to what extent this element is preserved. Specifically, the analysis has demonstrated that neither of the two translations of Heart of Darkness scrutinized here entirely preserves the blurriness conveyed by the different ways in which some is used in the original novel. This is evidenced by the fact that, to a greater or lesser extent, a significant number of occurrences are either omitted or translated using a word denoting specificity in both versions, which results in a loss of meaning from a stylistic point of view. This loss is more substantial in the version by Diéguez Rodríguez, in which more occurrences are neglected (see Table 4). However, the cases found in the version by García Ríos \& Sánchez Araujo also have an impact on the vagueness conveyed through Conrad's use of grammatical words, as (3a), (5a), (6a) and (7a) have shown. Finally, the analysis has also demonstrated that the translators did not recognize the role of some, as its rendering into Spanish does not actually pose any difficulties for translation. In sum, the use of a corpus approach to analyze two Spanish versions of Heart of Darkness has shed light on aspects hitherto underexplored from a translating point of view, thereby revealing how seemingly harmless microlinguistic alterations can affect the interpretation of the translated texts from a literary point of view, as some plays a stylistically significant role in the original novel. 


\section{Conclusion}

This article has set out to illustrate the potential of corpus approaches in the analysis of translated literary texts. As has been shown, a corpus methodology has made it possible to gauge the saliency of some in Heart of Darkness against the backdrop of a corpus of Conrad's novels, thus ascertaining its stylistic value in Heart of Darkness. This methodology has also made it possible to analyze systematically how the two Spanish translations render the 203 occurrences of some, somebody, somehow, someone, something, sometimes and somewhere, which play a significant role in creating the blurry atmosphere dominating the English novel. The corpus approach adopted has allowed a level of precision which would have been almost impossible to achieve manually, making it possible to measure the degree to which both versions maintain a subtle stylistic trait of the novel.

Finally, we hope that this article has also outlined a framework which could have broader applicability beyond the analysis of some in Spanish. To name but one example, the translation of seem, like and other aspects relevant to the well-known blurriness which dominates the story (see Section 2) can be also scrutinized using corpus approaches. These could help obtain a comprehensive picture of whether and to what extent blurriness is preserved in translated versions of the novel, either in Spanish or in any other language.

\section{REFERENCES}

BAKer, M. (1993): «Corpus Linguistics and Translation Studies: Implications and Applications». En Baker, M., Francis, G. \& Tognini-Bonelli, E.: Text and Technology: In Honour of John Sinclair. Amsterdam: John Benjamins, pages 233-250.

- (2004): «A Corpus-based View of Similarity and Difference in Translation». International Journal of Corpus Linguistics, 9.2, pages 167-193.

- (2011): In Other Words: A Coursebook on Translation. London, Routldege.

Č́rmáková, A. (2015): «Repetition in John Irving's Novel A Widow for One Year: A Corpus Stylistics Approach to Literary Translation». International Journal of Corpus Linguistics, 20.3, pages 355-377.

Conrad, J. (1973): Heart of Darkness. New York, Penguin Books [1902].

Diéguez Rodríguez, A. (2002): El corazón de las tinieblas. Madrid, Diario El PaísSantillana.

García Ríos, A. \& Sánchez Araujo, I. (2005): El corazón de las tinieblas. Madrid, Alianza [1976].

JI, M. (2012): «Hypothesis Testing in Corpus-Based Literary Translation Studies». In Oakes, M.P. \& Ji, M.: Quantitative Methods in Corpus-Based Translation Studies. Amsterdam: John Benjamins, pages 53-74. 
Kruger, A., Wallmach, K. \& Munday, J. (2011): Corpus-Based Translation Studies: Research and Applications. London, Continuum.

LaBrasca, R. (1988): «Two Visions of “The Horror!”». En Kimbrough, R.: Joseph Conrad: Heart of Darkness. New York: Norton, pages 288-293 [1979].

Laviosa, S. (2013): «Corpus Linguistics and Translation Studies». En Millán, C. \& Batrina, F.: The Routledge Handbook of Translation Studies. Abingdon: Routledge, pages 228-240.

Leech, G. \& Short, M. (2007): Style in Fiction. London, Longman [1981].

Patton, J.M. \& CAn, F. (2012): «Determining Translation Invariant Characteristics in James Joyce's Dubliners». En Oakes, M.P. \& Ji, M.: Quantitative Methods in CorpusBased Translation Studies. Amsterdam: John Benjamins, pages 209-230.

RABADÁN, R. (1991): Equivalencia y traducción: problemática de la equivalencia translémica inglés-español. León, Universidad de León.

Ruano San Segundo, P. (2017): «Corpus Methodologies in Literary Translation Studies: An Analysis of Speech Verbs in Four Spanish Translations of Hard Times». Meta, 62.1, pages 94-113.

SÁnchez Nieto, M.T. (2015): Corpus-Based Translation and Interpreting Studies: From Description to Application. Berlin, Frank and Timme.

Scotт, M. (2016): WordSmith Tools version 7. Stroud, Lexical Analysis Software.

Senn, W. (1980): Conrad's Narrative Voice. Bern, Francke.

Stubbs, M. (2005): «Conrad in the Computer: Examples of Quantitative Stylistic Methods». Language and Literature, 14.1, pages 5-24.

WATt, I. (1988): «Impressionism and symbolism in Heart of Darkness». En Kimbrough, R.: Joseph Conrad: Heart of Darkness. New York, Norton, pages 311-336 [1979].

Winters, M. (2005): A Corpus-based Study of Translator Style: Oeser's and Orth-Guttmann's German Translations of F. Scott Fitzgerald's The Beautiful and Damned. Dublin, Dublin City University.

Zanettin, F. (2012): Translation-Driven Copora. London, Routledge. 